\title{
The diagnostic value of serum leucine aminopeptidase
}

\author{
G. MERICAS, E. ANAGNOSTOU, ST. HADZIYANNIS, \\ AND S. KAKARI
}

From the Departments of Medicine and Chemical Pathology, the Evangelismos Hospital, Athens

SYNOPSIS Serum leucine aminopeptidase determination was found to be a useful screening procedure for hepatobiliary disease in jaundiced and unjaundiced patients. Values under 1,000 units are of no help in the differential diagnosis of jaundice but values above 1,000 units are highly indicative of in biliary obstruction. The differentiation of intra- from extrahepatic obstruction as well as of malignant from benign jaundice cannot generally be established by this single test.

A number of studies relating to the clinical value of serum leucine aminopeptidase determinations have already appeared (Arst, Manning, and Delp, 1959; Bressler, Forsyth, and Klatskin, 1960; Göggel, Creutzfeldt, and Murucas, 1960; Miller and Worsley, 1960; Pineda, Goldbarg, Banks, and Rutenburg, 1960a; Winsten and Seller, 1961). It is now accepted that serum leucine aminopeptidase activity does not suffice for early diagnosis of cancer of the pancreas as had been thought originally (Rutenburg, Goldbarg, and Pineda, 1958). The level of this enzyme is raised in serum almost exclusively in the presence of hepatobiliary and pancreatic disease (Arst et al., 1959; Hammond, Rosenak, and Khoo, 1960; Banks, Pineda, Goldbarg, and Rutenburg, 1960). Concerning the differential diagnosis of jaundice there are conflicting views. It is the purpose of the present paper to report findings on 400 determinations of serum leucine aminopeptidase activity performed between May 1961 and January 1962.

\section{MATERIALS AND METHODS}

Serum leucine aminopeptidase activity was assayed by a method adopted by the Biochemical Department of Messrs. Boehringer and Soehne (Mannheim) derived from those of Green, Tsou, Bressler, and Seligman (1955), Goldbarg and Rutenburg (1958), and Braun-Falco and Salfeld (1957). Undiluted serum, $0.05 \mathrm{ml}$., was incubated with $2.5 \mathrm{ml}$. of the buffered substrate solution (L-leucyl$\beta$-naphthylamide hydrochloride) at $37^{\circ} \mathrm{C}$. for one hour. The liberated $\beta$-naphthylamine was coupled immediately with diazotized 3-chloro - 4-nitraniline to a red azo dye. The colour density of the azo dye was measured with a Junior Coleman spectrophotometer at $492 \mu$.

Received for publication 30 April 1963.
Serum leucine aminopeptidase units were expressed in terms of micrograms of $\beta$-naphthylamine liberated from the substrate by the enzymatic action of $1 \mathrm{ml}$. of serum after one hour's incubation at $37^{\circ} \mathrm{C}$.

Serum leucine aminopeptidase activity was assayed in 400 sera obtained from 50 healthy persons (controls) and 195 in-patients; most of the patients were suffering from hepatobiliary diseases.

\section{RESULTS}

NORMAL VALUES Normal values obtained from 50 controls (25 males and 25 females) are shown in Table I. Significant differences have not been observed between the two sexes. The upper limits of normal were taken as the mean plus 2 standard deviations, that is $\mathbf{4 0 0}$ units.

HEPATOBILIARY DISEASES In a group of 117 patients with a variety of hepatobiliary diseases, 95 of them were jaundiced and 22 were not jaundiced. Between the unjaundiced patients there were cases of choledocholithiasis, hepatic metastases, infectious hepatitis, and calculous cholecystitis. Serum leucine amino- $N$ peptidase activity was increased in $91(95.6 \%)$ of the $\sigma$ jaundiced and $14(63.6 \%)$ of the unjaundiced $N$ patients, (Table II). There was no correlation $\underset{\mathrm{N}}{\mathrm{N}}$ between serum leucine aminopeptidase activity and 0 bilirubin in jaundiced patients. Serum analysis, $\underset{O}{\sigma}$ biopsy, operation, and clinical diagnosis beyond any $\stackrel{\bar{D}}{\bar{D}}$ doubt were made in the case of 80 of these patients. $\stackrel{D}{\rightarrow}$ Individual serum leucine aminopeptidase values for 0 each case of this group are shown in Table III. In Fig. 1 a comparison is made between leucine aminopeptidase and alkaline phosphatase in cases of $\frac{\mathbb{D}}{}$ obstructive jaundice. 
TABLE I

NORMAL VALUES FOR SERUM LEUCINE AMINOPEPTIDASE ACTIVITY

\begin{tabular}{|c|c|c|c|c|c|}
\hline & \multirow[t]{2}{*}{ No. of Patients } & \multirow[t]{2}{*}{ Age (yr.) } & \multicolumn{3}{|c|}{ Serum Leucine Aminopeptidase Activity (units/ml.) } \\
\hline & & & Range & Mean & $\pm S . D$. \\
\hline Males & 25 & $20-70$ & $130-380$ & 253 & $71 \cdot 3$ \\
\hline Females & 25 & $12-65$ & $130-370$ & 243 & $77 \cdot 4$ \\
\hline Total & 50 & $12-70$ & $130-380$ & 248 & $75 \cdot 4$ \\
\hline
\end{tabular}

TABLE II

SERUM LEUCINE AMINOPEPTIDASE LEVELS IN HEPATOBILIARY AND MISCELLANEOUS DISEASES

\begin{tabular}{|c|c|c|c|c|c|c|}
\hline & & No. of Patients & Serum $L$ & ninopeptid & Activity & \\
\hline & & & Normal & & Raised & \\
\hline & & & No. & & No. & \\
\hline Miscellaneous diseases & & 50 & 47 & $(94 \%)$ & 3 & $(6 \%)$ \\
\hline Hepatobiliary diseases & $\begin{array}{l}\text { Jaundiced } \\
\text { Not jaundiced } \\
\text { Total }\end{array}$ & $\begin{array}{r}95 \\
22 \\
117\end{array}$ & $\begin{array}{r}4 \\
8 \\
12\end{array}$ & $\begin{array}{l}(4.4 \%) \\
(36.4 \%) \\
(10.3 \%)\end{array}$ & $\begin{array}{r}91 \\
14 \\
105\end{array}$ & $\begin{array}{l}(95.6 \%) \\
(63.6 \%) \\
(89.7 \%)\end{array}$ \\
\hline
\end{tabular}

TABLE III

SERUM LEUCINE AMINOPEPTIDASE ACTIVITY IN HEPATOBILIARY AND PANCREATIC DISEASE

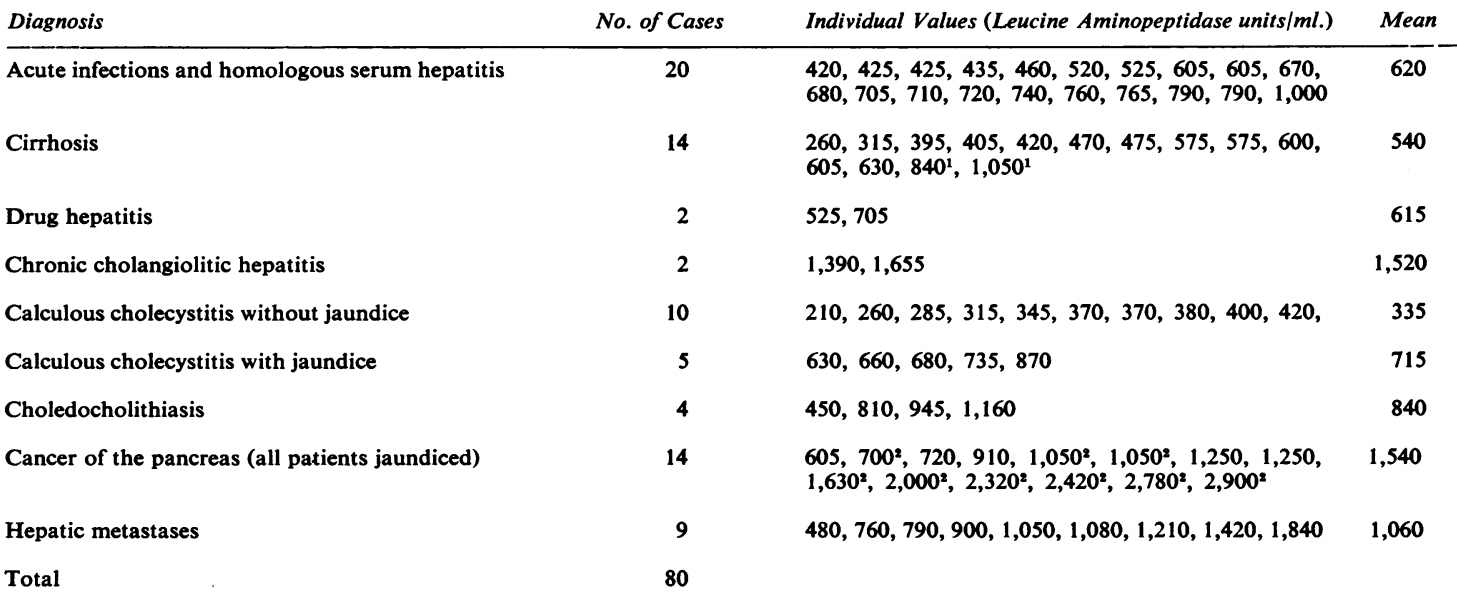

${ }^{1}$ Biliary cirrhosis.

${ }^{2}$ With hepatic metastases.

CONGESTIVE HEART FAILURE Of 15 patients with congestive heart failure serum leucine aminopeptidase was increased in eight of them $(420,425,425$, $460,475,480,550$, and 575 units). Some of the cases with normal values suffered from severe right heart failure and the liver was greatly enlarged.

MisCELLANEOUS Of 50 patients with a variety of diseases not involving the hepatobiliary system and pancreas, serum leucine aminopeptidase activity was normal in 47 and slightly increased in three of them $(420,425,460$ units).

SERIAL DETERMINATIONS In cases of acute infective hepatitis serum leucine aminopeptidase activity returned to normal usually late during the posticteric phase. Figure 2 shows the results of serial leucine aminopeptidase determinations and other tests of liver function in a patient with homologous serum hepatitis. In cases of malignant obstruction 


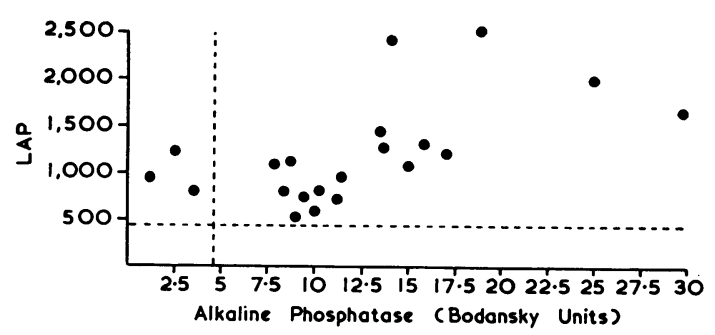

FIG. 1. Leucine aminopeptidase and alkaline phosphatase levels compared in obstructive jaundice.

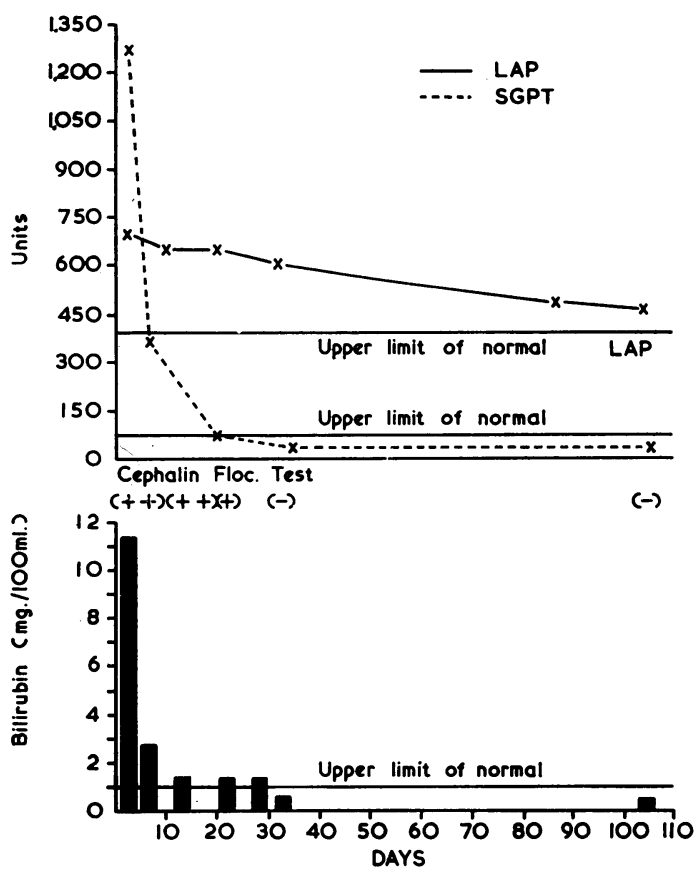

FIG. 2 Results of serial leucine aminopeptidase determinations and other tests of liver function in a patient with homologous serum hepatitis.

serum leucine aminopeptidase activity was persistently raised. The same was found to occur in cases of chronic cholangiolitic hepatitis and biliary cirrhosis.

\section{DISCUSSION}

The results of the present study (Tables II and III) support the well-established view that serum leucine aminopeptidase is a specific and sensitive index of hepatobiliary disease (Arst et al., 1959; Bressler et al., 1960; Miller and Worsley, 1960; Banks et al., 1960).
It is interesting to note that serum leucine aminopep-o tidase levels were elevated not only in the jaundiced patients but also in those not jaundiced, though to ac much lower extent (Table II). It must also be emphasized that in some cases of the anicteric group serum듬 leucine aminopeptidase activity was raised whereas $\overline{\overline{0}}$ results of the commonly performed liver function $\mathbb{8}$ tests (alkaline phosphatase and transaminases included) were normal. The above finding was ${ }^{\infty}$ observed in cases of acute hepatitis in the post-icteric $\vec{O}$ phase (Fig. 2), in one case of hepatic metastases, and $\overrightarrow{-}$ in two cases of choledocholithiasis; on the other $\vec{\sigma}$ hand most anicteric patients with calculous cholecystitis (Table III) had a normal serum leucine? aminopeptidase level. Similar findings have also been. $\overrightarrow{.}$ reported by Pineda, Goldbarg, and Rutenburg o (1960b).

Some authors (Göggel, Kreutzfeldt, and Murucas,으 1960; Pineda et al., 1960a and b; Shay, Sun, and Siplet, 1960) believe that biliary obstruction-intraor extrahepatic-is mainly responsible for raising? serum leucine aminopeptidase levels though hepatic damage may also contribute to a lesser degree. Since $\rightarrow$ leucine aminopeptidase is normally found in bile\&̆ (Pineda et al., 1960a and b) it is possible that biliary. obstruction impairs the excretion of this enzyme resulting in raised levels in serum. Against this concept and in favour of an overproduction theory, is the finding of raised serum leucine aminopeptidase $\stackrel{2}{\circ}$ activity in anicteric patients. Regardless of the $\stackrel{\mathbb{Q}}{\varrho}$ pathogenetic mechanism of raised serum leucine $\overrightarrow{\vec{A}}$ aminopeptidase levels the interesting clinical view- $\frac{3}{3}$ point is whether a such highly elevated level in serum reflects the existence of cholestasis and whether this may be helpful in the differential diagnosis of jaundice. In our study values under 1,000 units were? commonly observed in all groups of hepatobiliary disease. Values above 1,000 units have been found only in those cases in which biliary obstruction existed (cancer of the pancreas with jaundice, hepatic metastases, calculous biliary disease, chronic cholan- $\frac{\rho}{\square}$ giolitic hepatitis). It is therefore logical to assume that serum leucine aminopeptidase values under 1,000 units simply indicate the involvement of the $N$ hepatobiliary tract and that values above 1,000 . indicate the existence of biliary obstruction, whatever 0 its cause (malignant or benign) and localization $\omega$ (intrahepatic or extrahepatic). Further differentiation? of the cause and the localization of biliary obstruction is not usually possible even with serial determinations.

It must be noted that extremely high values (above 0 2,000 units) were observed only in cases of obstructive jaundice due to cancer of the pancreas with $\stackrel{\mathbb{D}}{\stackrel{D}{\circ}}$ hepatic metastases. This has been noted by other $\stackrel{\mathbb{Q}}{\circ}$ authors (Rutenberg, Goldbarg, and Pineda, $1958 ;$;O 
René and Meelinkoff, 1960); whether this is due to a complete continuous biliary obstruction that only carcinomas can create or is due to the neoplastic tissue itself is not yet known.

Despite a certain amount of disagreement, some authors (Göggel et al., 1960; Banks et al., 1960) consider that the serum leucine aminopeptidase test is a more sensitive index of biliary obstruction than the commonly performed non-specific serum alkaline phosphatase determination. In our study serum leucine aminopeptidase activity was always abnormal when alkaline phosphatase was elevated but not vice-versa. The scatter diagram (Fig. 1) shows no significant differences between leucine aminopeptidase and alkaline phosphatase in cases of obstructive jaundice if values of 1,000 leucine aminopeptidase units and 12 alkaline phosphatase Brodansky units are respectively taken as indicative of obstruction.

\section{REFERENCES}

Arst, H. E., Manning, R. T., and Delp, M. (1959). Amer. J. med. Sci. 238, 598.

Banks, B. M., Pineda, E. P., Goldbarg, J. A., and Rutenburg, A. M. (1960). New Engl. J. Med., 263, 1277.

Braun-Falco, O., and Salfeld, K. (1957). Arch. klin. exp. Derm., 204, 407.

Bressler, R., Forsyth, B. R., and Klatskin, G. (1960).J. Lab. clin. Med., $56,417$.

Göggel, K, H., Creutzfeldt, W., and Murucas, J. (1960). Dsch. med., Wschr., 85, 1756.

Goldbarg, J. A., and Rutenburg, A.M.(1958). Cancer(Philad.), 11, 283.

Green, M. N., Tsou, K. C., Bressler, R., and Seligman, A. M. (1955). Arch. Biochem., 57, 458.

Hammond, J. B., Rosenak, B. D., and Khoo, E. C. (1960). Amer. J. dig. Dis., 5, 233.

Miller, A. L., and Worsley, L. (1960). Brit. med. J., 2, 1419.

Pineda, E. P., Goldbarg, J. A., Banks, B. M., and Rutenburg, A. M. (1960a) Gastroenterology, 38, 698.

- , and Rutenburg, A. M. (1960b) Surg. Forum, 10, 249.

René, R. M., and Meelinkoff, S. M. (1960). Amer. J. dig. Dis., 5, 899.

Rutenburg, A. M., Goldbarg, J. J., and Pineda, E. P. (1958). New Engl. J. Med., 259, 469.

Shay, H., Sun, D. C. H., and Siplet, H. (1960). Amer.J. dig. Dis., 5, 217. Winsten, S., and Seller, R. H. (1961). J. Einstein med. Cent., 9, 33. 